\title{
The Channel-Kinase TRPM7 as Novel Regulator of Immune System Homeostasis
}

\author{
Wiebke Nadolni and Susanna Zierler * (D) \\ Walther Straub Institute of Pharmacology and Toxicology, Faculty of Medicine, LMU Munich, Goethestr. 33, \\ 80336 Munich, Germany; wiebke.nadolni@lrz.uni-muenchen.de \\ * Correspondence: susanna.zierler@lrz.uni-muenchen.de; Tel.: +49-89-2180-75-722
}

Received: 13 July 2018; Accepted: 13 August 2018; Published: 17 August 2018

\begin{abstract}
The enzyme-coupled transient receptor potential channel subfamily M member 7, TRPM7, has been associated with immunity and immune cell signalling. Here, we review the role of this remarkable signalling protein in lymphocyte proliferation, differentiation, activation and survival. We also discuss its role in mast cell, neutrophil and macrophage function and highlight the potential of TRPM7 to regulate immune system homeostasis. Further, we shed light on how the cellular signalling cascades involving TRPM7 channel and/or kinase activity culminate in pathologies as diverse as allergic hypersensitivity, arterial thrombosis and graft versus host disease $\left(\mathrm{G}_{\mathrm{V}} \mathrm{HD}\right)$, stressing the need for TRPM7 specific pharmacological modulators.
\end{abstract}

Keywords: TRPM7; kinase; inflammation; lymphocytes; calcium signalling; SMAD; TH17; hypersensitivity; regulatory $\mathrm{T}$ cells; thrombosis; graft versus host disease

\section{Introduction}

The melastatin-like TRPM7 channel conducts divalent cations, specifically calcium $\left(\mathrm{Ca}^{2+}\right)$, magnesium $\left(\mathrm{Mg}^{2+}\right)$ and zinc $\left(\mathrm{Zn}^{2+}\right)$ [1-3]. It has been implicated in cellular and systemic $\mathrm{Mg}^{2+}$ homeostasis [4-6], $\mathrm{Zn}^{2+}$-mediated toxicity [7,8] and intracellular $\mathrm{Ca}^{2+}$ signalling [9-12]. The TRPM7 channel is considered to be constitutively active and its activity to be negatively regulated by intracellular cations $\left(\mathrm{Mg}^{2+}, \mathrm{Ba}^{2+}, \mathrm{Sr}^{2+}, \mathrm{Zn}^{2+}, \mathrm{Mn}^{2+}\right), \mathrm{Mg}$-ATP, polyamines, chloride $\left(\mathrm{Cl}^{-}\right)$and bromide $\left(\mathrm{Br}^{-}\right)$concentrations, low intracellular $\mathrm{pH}$ and hydrolysis of the acidic phospholipid phosphatidylinositol 4,5-bisphosphate $\left(\mathrm{PIP}_{2}\right)$ [13-16]. Resting free cytosolic $\mathrm{Mg}^{2+}\left(0.5-1 \mathrm{mM}\left[\mathrm{Mg}^{2+}\right]_{\mathrm{c}}\right)$ and Mg-ATP (3-9 mM) concentrations [17] seem to be sufficient to block native TRPM7 channel activity [4,18-20]. TRPM7's unique enzyme encodes a serine-threonine kinase closely related to eukaryotic elongation factor-2 kinase [21], phosphorylating mainly within $\alpha$-helical loops [22]. A few in vitro TRPM7 kinase substrates have been identified early on, including annexin A1 [23,24], myosin II heavy chain [25] and PLC $\gamma 2$ [26]. Only recently, with the development of novel mouse models, the first native kinase substrate, SMAD2, was discovered, paving the way for more to follow $[11,20,27]$.

Genetic disruption of TRPM7 in mice $\left(\operatorname{Trpm} 7^{-/-}\right)$is embryonic lethal $[4,28]$. Deletion of the exons encoding the TRPM7 kinase domain only $\left(\operatorname{Trpm} 7^{\Delta k / \Delta k}\right)$ also leads to early embryonic lethality [4]. However, the latter phenotype could be attributed to a reduction in channel activity in this mutant, particularly, as mice bearing a single point mutation at the active site of the kinase (K1646R, $\left.\operatorname{Tr} m m 7^{R / R}\right)$, thus inactivating its catalytic activity, are viable and display no obvious phenotype $[29,30]$. Heterozygous $\operatorname{Trpm} 7^{+/ \Delta k}$ mice are also viable but develop hypomagnesaemia upon $\mathrm{Mg}^{2+}$ restriction [4]. Deletion of the TRPM7 kinase domain at amino acid (aa) 1538 yields in reduced current amplitudes, while caspase-induced deletion at aa 1510 results in enhanced TRPM7 currents $[4,31]$. Inactivation of kinase activity via the K1646R mutation $\left(\operatorname{Tr} p m 7^{R / R}\right)$, though, does not affect current development [29,30,32] (Figure 1). However, it was reported to show increased 
basal current activity right after break-in in macrophages [29]. Recently, it was shown that the $\mathrm{Mg}^{2+}$-sensitivity of the TRPM7 channel is reduced almost two-fold in kinase-deficient $\operatorname{Tr} p m 7^{R / R}$ mouse mast cells. The tested $\mathrm{Mg}^{2+}$ concentrations, however, suggest that this effect will not influence TRPM7 currents in intact cells with $\left[\mathrm{Mg}^{2+}\right]_{\mathrm{c}}$ close to $1 \mathrm{mM}$ [20]. Accordingly, how TRPM7 channel and kinase activities affect each other is still incompletely understood. It is thought that they are interdependent in that $\mathrm{Mg}^{2+}$ enters through the channel pore and the kinase domain requires $\mathrm{Mg}^{2+}$ ions to function $[3,22]$, while the kinase domain rather than the catalytic activity are crucial for channel function [4,29-31].

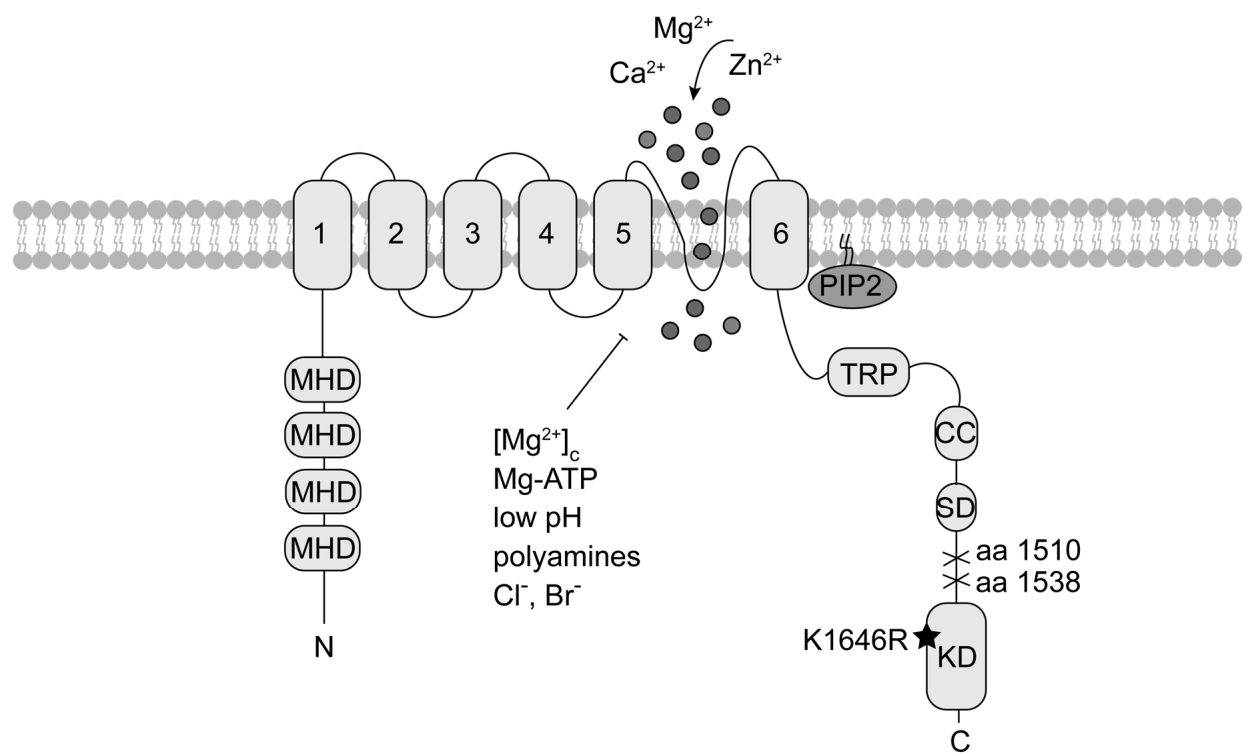

Figure 1. TRPM7 topology. Each TRPM7 protein consists of six transmembrane segments (1 to 6) with the channel pore located between segment 5 and 6 . Within the $\mathrm{N}$-terminus are melastatin homology domains (MHD), characteristic for TRPM family members. The cytoplasmic $C$-terminus contains a transient receptor potential domain (TRP), a coiled-coil domain (CC) and a kinase substrate domain (SD) upstream the atypical $\alpha$-type serine/threonine protein kinase domain (KD). Mutation at the catalytic side of the kinase (K1646R) abolishes kinase activity without affecting current activity. Deletion of the KD at different amino acids (aa) results in either enhanced or reduced current activity. The black star indicates the location of the point mutation, crosses mark the kinase deletion. TRPM7 is negatively regulated by depletion of phosphatidylinositol 4,5-bisphosphate $\left(\mathrm{PIP}_{2}\right)$, physiologic free cytosolic magnesium concentrations $\left[\mathrm{Mg}^{2+}\right]_{\mathrm{c}}, \mathrm{Mg}$-ATP, polyamines, low $\mathrm{pH}$ and chloride $\left(\mathrm{Cl}^{-}\right)$and bromide $\left(\mathrm{Br}^{-}\right)$concentrations.

TRPM7 kinase requires $\mathrm{Mn}^{2+}$ or $\mathrm{Mg}^{2+}$ for its activity and uses mainly Mg-ATP for phosphorylation [22]. Massive auto-phosphorylation of TRPM7 increases kinase activity and substrate recognition [33-36]. Considering the ubiquitous expression of TRPM7, it is not surprising that the protein has a fundamental and non-redundant role in cellular physiology $[1,37]$. It is involved in processes as diverse as proliferation, growth, migration, apoptosis, differentiation and exocytosis [38]. Tissue-specific deletion of TRPM7 in thymocytes or macrophages, as well as inactivation of the kinase activity $\left(\operatorname{Trpm} 7^{R / R}\right)$ in mice, highlight the importance of this unique signalling protein for an operating immune system that is still kept in check $[20,28,39]$.

\section{The Channel-Kinase TRPM7 in Immune Cell Signalling}

\subsection{TRPM7 Kinase Regulates Mast Cell Reactivity}

Mast cells are associated with the progression of different pathologies such as immediate and delayed hypersensitivity reactions, arthritis, atherosclerosis, heart failure, as well as neuroinflammatory diseases [40-42]. Upon stimulation, mast cells release granules, filled with inflammatory mediators such as histamine, proteases, cytokines and growth factors $[43,44]$. Mast cells are present in all 
organs in close proximity to blood vessels, neurons and lymphatic vessels, thus disseminating local inflammatory signals [40]. While classically, mast cells are activated via crosslinking of the IgE receptor $\left(\mathrm{F}_{\mathrm{c}} \varepsilon \mathrm{RI}\right)$ upon antigen binding [45], their activation can be triggered by many other stimuli including toll-like receptor (TLR) ligands, complement and neuropeptides. Receptor stimulation in mast cells leads to a network of stimulatory and inhibitory signals [44] encoded via intricate $\mathrm{Ca}^{2+}$ signalling events $[46,47]$. Store operated $\mathrm{Ca}^{2+}$ entry is essential for mast cell activation in vitro and in vivo $[48,49]$. Recently, TRPM7 has been implicated in receptor-induced $\mathrm{Ca}^{2+}$ release as well as store-operated $\mathrm{Ca}^{2+}$ entry $[9,12]$. In primary human lung mast cells (HLMCs) and in the human mast cell lines, LAD2 and HMC-1, TRPM7 expression and function was shown to be essential for cell survival. Using adenoviral-mediated knock-down of TRPM7 in HLMC or HMC-1 authors observed enhanced cell death, which was not rescued by extracellular $\mathrm{Mg}^{2+}$ supplementation [50]. First indications that TRPM7 is involved in degranulation processes and release of cytokines in rat bone marrow-derived mast cells (BMMCs) were gained in 2014. TRPM7 mRNA expression levels were significantly higher in asthmatic rat BMMCs than in controls. Genetic or pharmacological inhibition of TRPM7 significantly decreased $\beta$-hexosaminidase activity and secretion of histamine as well as the release of the pro-inflammatory cytokines IL-6, IL-13 and TNF- $\alpha$ in the asthmatic group compared to the control group. Authors concluded that inhibition of TRPM7 currents reduces mast cell degranulation and cytokine release [51]. However, functional TRPM7 channel or kinase activities were not shown. The pharmacological antagonist used to inhibit TRPM7, 2-Aminoethoxydiphenyl Borate (2-APB), supposedly only blocks channel and not kinase activity but has various off-target effects. Importantly, at the applied concentrations (100-200 $\mu \mathrm{M})$ 2-APB blocks store operated $\mathrm{Ca}^{2+}$ entry (SOCE) via inhibition of $\mathrm{Ca}^{2+}$ release activated calcium (CRAC) channels [52]. Thus, it is possible that observed 2-APB effects were in fact not mediated by TRPM7 but SOCE. Authors, however, confirm the reduction in $\beta$-hexaminidase activity as well as in histamine and cytokine release, using a lentiviral siRNA-mediated knock-down of TRPM7 in primary BMMCs [51]. Nonetheless, the question remained, whether kinase and/or channel activity were responsible for the observed phenotype. As kinase-deficient $\operatorname{Trpm} 7^{R / R}$ mutant mouse mast cells showed normal current amplitudes but no kinase activity, this model allowed the independent study of TRPM7 channel versus kinase moieties in mast cells [32]. Utilizing the two TRPM7 kinase mutant mouse models $\left(\operatorname{Tr} p m 7^{+/ \Delta k}, \operatorname{Tr} p m 7^{R / R}\right)$, it was shown that the kinase regulated $G$ protein-coupled receptor-activated histamine release, independently of channel activity. TRPM7 kinase activity, moreover, regulated $\mathrm{Ca}^{2+}$-sensitivity of $\mathrm{G}$ protein-triggered mast cell degranulation. TRPM7 kinase-deficiency resulted in suppressed IgE-dependent exocytosis and slower cellular degranulation rates. Besides, extracellular $\mathrm{Mg}^{2+}$ was necessary to guarantee regulated IgE-induced exocytosis. Authors concluded that the TRPM7 kinase activity controls murine mast cell degranulation and histamine release independently of TRPM7 channel function [32]. Thus, TRPM7 might inflict its immune-modulatory role on mast cells via its kinase domain.

\subsection{TRPM7 in Neutrophil Migration}

Neutrophils, the most abundant leukocytes in the blood, are one of the key players of the innate immune system, contributing to the clearance of acute inflammation and bacterial infection [53]. During acute inflammation neutrophils are one of the first responding cells. The signalling cascades triggered after neutrophil activation start with migration of neutrophils towards the inflammatory site. The cascade ends with elimination of pathogens via secretion of chemokines, which attract other leukocytes, phagocytosis to maintain tissue homeostasis and degranulation and release of neutrophil extracellular traps (NETs) to prevent the spread of the infection. It is well established that $\mathrm{Ca}^{2+}$ signalling is pivotal for the recruitment cascade and activation of neutrophils, highlighting the importance of ion channels for neutrophil function $[54,55]$. TRPM7 channel activity has been implicated as a regulator of cell migration by facilitating $\mathrm{Ca}^{2+}$ oscillations [56-58]. Using a human neutrophil cell line, it was shown that TRPM7 is recruited into lipid rafts in a CD147-dependent manner. Knock-down of CD147, a glycoprotein required for neutrophil recruitment and chemotaxis, caused 
significant decrease in lipid raft localization of TRPM7. Thus, TRPM7 was suggested to be involved in the CD147-triggered $\mathrm{Ca}^{2+}$-induced chemotaxis, adhesion and invasiveness of human neutrophils [59]. However, Wang and colleagues did not show functional TRPM7 ion channel activity and one needs to keep in mind that neutrophil-like cell lines are controversially discussed regarding their comparability to primary neutrophils [53]. During acute lung injury (ALI), the permeability of the alveolar-capillary membrane is increased, which in turn can lead to migration of neutrophils [60]. A septic rat model treated with salvianolic B showed that sepsis-induced ALI was reduced due to decreased levels of TRMP6 and TRPM7 mRNA in lung tissue, potentially linking TRPM7 to neutrophil migration and infiltration [61]. As patients with inherited neutrophil deficiencies suffer from severe infections that are often fatal, underscoring the importance of this cell type in immune defence, it is critical to gain a better understanding of the role of TRPM7 channel and kinase activities in the signalling cascades triggering neutrophil migration [53].

\subsection{TRPM7 Guides Macrophage Activation and Polarization}

Blood monocytes and tissue macrophages are major components of innate immunity, strategically positioned throughout the body tissues to orchestrate inflammatory processes. Similar to neutrophils, they maintain tissue homeostasis via phagocytosis of dead cells, debris or potentially harmful pathogens. As antigen presenting cells they are able to activate and coordinate the adaptive immune system $[62,63]$. Various TRP proteins have been associated with macrophage-mediated inflammatory responses [64]. TRPM7 has also been linked to the activation and proliferation of monocytes and macrophages [29,65-68]. However, controversies on the role of TRPM7 for macrophage activation in response to LPS remain $[39,68]$. On the one hand, TRPM7 channel activity was suggested to be essential for macrophage proliferation and polarization into the alternate or anti-inflammatory M2-subtype [68]. LPS and co-stimulatory cytokines IFN- $\gamma$ (pro-inflammatory M1-type) or IL-4 and IL-13 (anti-inflammatory M2-type) trigger the polarization of macrophages [69,70]. Interestingly, the activity of TRPM7 increased significantly in response to stimulation with IL-4. The TRPM7 inhibitor NS8593 [71] blocked IL-4 and M-CSF induced proliferation and reduced the inhibitory effect of IL-4 or M-CSF on the LPS-induced expression of the pro-inflammatory cytokine TNF- $\alpha$, thus, counteracting the differentiation into the M2 subtype [68]. On the other hand, more recently, TRPM7 channel activity has been implicated in macrophage activation in response to LPS and LPS-induced peritonitis [39]. In TRPM7-deficient macrophages (Trpm $7^{f l f l}(L y s M C r e)$ ) IL-1 $\beta$ secretion was significantly reduced and also the gene expression upon LPS stimulation was altered, indicating a key function of TRPM7 in the activation process of macrophages. In addition, it was found that TRPM7 is pivotal for the endocytosis of LPS-TLR4-CD14 signalling complexes with TRPM7-deficient macrophages showing significantly reduced internalization of TLR4 and CD14. Schappe et al. demonstrated that these defects upon LPS stimulation were due to diminished TRPM7-mediated $\mathrm{Ca}^{2+}$ influx. They speculate that TRPM7 not only controls TLR4 internalization but also regulates downstream IRF3 and NFKB signalling by mediating cytosolic $\mathrm{Ca}^{2+}$ elevations. Moreover, in a LPS-dependent model of peritonitis, Trpm 7 flffl (LysM Cre) mice had decreased serum cytokine levels after LPS treatment, preventing pathological inflammation. Specifically, the expression levels of Tnfa and Illb were significantly reduced, resulting in a diminished recruitment of immune cells into the peritoneum. Thus, Trpm $7 f$ flfl (LysM Cre) mice were protected from the development of LPS-induced peritonitis. Consequently, it was suggested that TRPM7 channel blockade could be beneficial for the treatment of chronic infections or septic shock [39]. The difference in the macrophage response to LPS might depend on different protocols used. However, to date there is no consensus, whether LPS induces $\mathrm{Ca}^{2+}$ elevations resulting in macrophage activation. Several studies have found no changes in cytosolic $\mathrm{Ca}^{2+}$ concentrations in response to LPS treatment in macrophages $[72,73]$.

The role of TRPM7 kinase activity in macrophage or dendritic cell function is far less understood. TRPM7 kinase-deficient mice $\left(\operatorname{Tr} p m 7^{R / R}\right)$ show no defects in percentages of macrophages [29]. Also, 
$\operatorname{Trpm} 7^{R / R} \mathrm{CD} 11 \mathrm{c}^{+}$dendritic cells develop normally and display regular major histocompatibility complex II (MHCII) and integrin expression [20].

\subsection{TRPM7 Affects Lymphocyte Functions}

Lymphocytes forming the adaptive or acquired immune response are activated and regulated by cells of the innate immune system, that is, macrophages and provide immunologic memory [74]. Antigen specific lymphocytes respond to pathogens with activation induced proliferation and clonal expansion. This temporal proliferative burst is terminated with a return to cell quiescence and eventual cell death. The autonomous timing of proliferation ensures an appropriate response magnitude whilst preventing uncontrolled expansion. Thus, a detailed understanding of the regulatory principles governing lymphocyte activation, proliferation, differentiation and survival is essential to a cohesive picture of the immune system homeostasis [75].

\subsubsection{TRPM7 Kinase Regulates Intracellular Calcium Signals and Proliferation in Lymphocytes}

Upon $\mathrm{T}$ cell receptor (TCR) or B cell receptor (BCR) stimulation, phospholipase C (PLC) is activated, catalysing the hydrolysis of $\mathrm{PIP}_{2}$ into diacylglycerol $(\mathrm{DAG})$ and inositol $(1,4,5)$ triphosphate $\left(\mathrm{IP}_{3}\right)$. Subsequently, $\mathrm{IP}_{3}$ triggers $\mathrm{Ca}^{2+}$-release from the endoplasmatic reticulum (ER) $\mathrm{Ca}^{2+}$-store via the $\mathrm{IP}_{3}$-receptor $\left(\mathrm{IP}_{3} \mathrm{R}\right)$. Upon depletion of $\mathrm{Ca}^{2+}$ from the ER lumen, the stromal interaction molecule (STIM) translocates to the plasma membrane and triggers SOCE via CRAC channels. This prolonged increase in intracellular $\mathrm{Ca}^{2+}$ concentrations is essential for the nuclear factor of activated $\mathrm{T}$ cells (NFAT) to translocate into the nucleus and induce transcription of genes essential for cell proliferation and clonal expansion (Figure 2) [38].

Recently, Romagnani et al. revealed that TRPM7 kinase-dead $\left(\operatorname{Tr} p m 7^{R / R}\right) \mathrm{CD} 4^{+} \mathrm{T}$ cells show slightly but significantly decreased $\mathrm{Ca}^{2+}$ signals upon stimulation with plate-bound anti-CD3/CD28 antibodies, whereas basal cytosolic $\mathrm{Ca}^{2+}$ concentrations $\left(\left[\mathrm{Ca}^{2+}\right]_{\mathrm{c}}\right)$ were unaltered [20]. These experiments were performed using extracellular $2 \mathrm{mM} \mathrm{Ca}^{2+}$ concentrations. Similarly, Beesetty et al. showed that receptor-mediated $\mathrm{Ca}^{2+}$ signalling was significantly diminished in $T r p m 7^{R / R} \mathrm{~T}$ cells using anti-CD3 crosslinking in $0.4 \mathrm{mM}$ extracellular $\mathrm{Ca}^{2+}$ levels, and differences in $2 \mathrm{mM} \mathrm{Ca}^{2+}$ concentrations were even more pronounced. Nevertheless, basal $\left[\mathrm{Ca}^{2+}\right]_{c}$ was also unchanged. In addition, SOCE was decreased in $\operatorname{Trpm} 7^{R / R}$ splenocytes upon pre-treatment with phorbol 12-myristate 13-acetate (PMA) and ionomycin, while there was no difference in ER-store $\mathrm{Ca}^{2+}$ content. Basal $\left[\mathrm{Ca}^{2+}\right]_{\mathrm{c}}$, however, were lower in PMA and ionomycin pre-activated $\operatorname{Trpm} 7^{R / R}$ T cells compared to wild-type (WT) [10]. These results are in line with recent studies, suggesting that TRPM7 regulates store-operated $\mathrm{Ca}^{2+}$ entry. Faouzi et al. linked TRPM7 channel and kinase moieties to direct involvement in SOCE. Trpm7-deficient chicken B lymphocytes exhibited down-regulation of SOCE, which was mainly attributed to missing kinase activity [12]. Moreover, it was shown that TRPM7 channels seem to be essential to sustain the $\mathrm{Ca}^{2+}$ content of intracellular stores in resting cells. Authors speculate that TRPM7 kinase may directly phosphorylate STIM2, thereby influencing $\mathrm{Ca}^{2+}$ entry via SOCE, yet found no effect on phosphorylation of STIM1 or STIM2 [12].The first indication that TRPM7 activity is involved in SOCE was found in 2005. Matsushita and colleagues reported that SOCE, in response to thapsigargin-induced store depletion, was increased in HEK293 cells transfected with WT TRPM7 but did not change in cells transfected with a kinase domain-deleted TRPM $7^{\triangle K D}$ (aa 1-1599) mutant construct, compared to mock transfected controls. However, the described TRPM ${ }^{\triangle K D}$ mutant displayed almost no current activity, leaving the question of the role of TRPM7 channel versus kinase moieties unanswered [76]. Also, the impact of TRPM7 kinase activity on T cell proliferation efficiency, following $\mathrm{Ca}^{2+}$ signalling events, remains controversial. While Romagnani et al. discovered that $\operatorname{Tr} m m 7^{R / R} \mathrm{~T}$ cells proliferate independently of their kinase activity in response to TCR stimulation (plate-bound anti-CD3/CD28) [20], Beesetty et al. showed a reduced $\mathrm{T}$ cell proliferation, in response to PMA and ionomycin treatment during the first 24 hours, which was compensated for after 48 and 72 hours [10]. As the reported reduction in $\mathrm{Ca}^{2+}$ signalling was very small, using plate-bound anti-CD3/CD28 antibodies, it is not surprising 
that $\operatorname{Trpm} 7^{R / R} \mathrm{~T}$ cell proliferation was not altered [20]. The decrease in SOCE upon pre-treatment with PMA ionomycin in $\operatorname{Tr} p m 7^{R / R}$ splenocytes however, was much more pronounced, resulting in reduced proliferation [10]. The combination of PMA—directly activating protein kinase $\mathrm{C}$-with the calcium ionophore ionomycin, which increases $\left[\mathrm{Ca}^{2+}\right]_{\mathrm{c}}$, is a fast and powerful stimulus, circumventing classical receptor activation. Thus the observed alterations in proliferation depend on the experimental conditions used, suggesting that TRPM7 kinase might influence proliferation depending on the stimuli and that receptor-operated mechanisms might be compensating $[10,20]$. Summarizing, these studies highlight a potential role of TRPM7 kinase activity in regulating $\mathrm{Ca}^{2+}$ signalling and subsequent activation processes in T cells and suggest TRPM as key regulator of the temporal proliferative burst. However, how exactly TRPM7 channel and kinase activities interplay to regulate $\mathrm{Ca}^{2+}$ signalling and subsequent proliferation in T lymphocytes still needs further investigation.

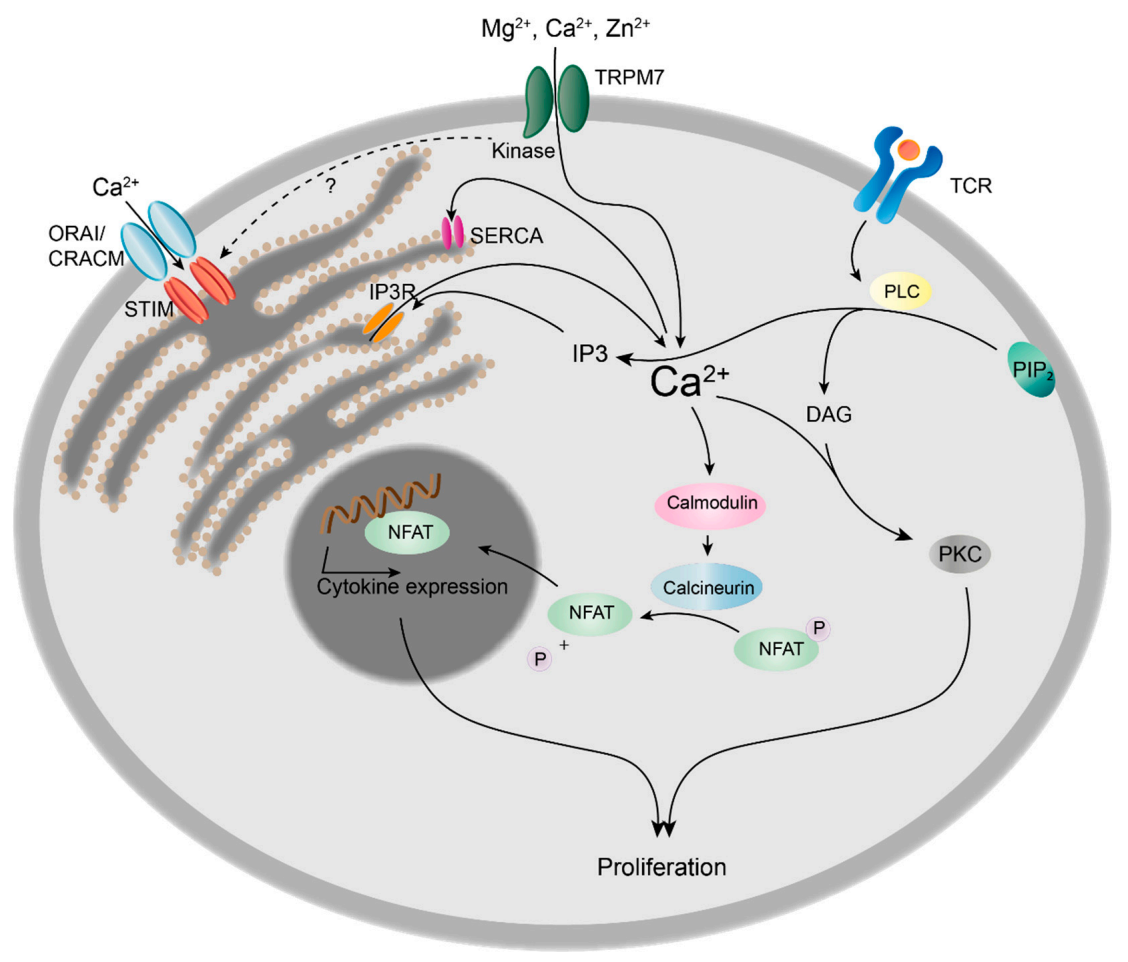

Figure 2. Role of TRPM7 kinase in calcium signalling and proliferation of $\mathrm{T}$ cells. Upon $\mathrm{T}$ cell receptor (TCR) binding, phospholipase C (PLC) is activated and hydrolyses phosphatidylinositol 4,5-biphosphate $\left(\mathrm{PIP}_{2}\right)$ to inositol 1,4,5-triphosphate $\left(\mathrm{IP}_{3}\right)$ and diacylglycerol (DAG). DAG in conjunction with $\mathrm{Ca}^{2+}$ activates protein kinase $\mathrm{C}(\mathrm{PKC})$, thus inducing cell proliferation. $\mathrm{IP}_{3}$ induces $\mathrm{Ca}^{2+}$ release from the endoplasmic reticulum (ER) via $\mathrm{IP}_{3}$ receptor $\left(\mathrm{IP}_{3} \mathrm{R}\right)$, followed by the translocation of the stromal interaction molecule (STIM) to the plasma membrane. STIM triggers $\mathrm{Ca}^{2+}$ influx from the extracellular space via ORAI/CRACM channels. $\mathrm{Ca}^{2+}$ is rapidly removed from the cytosol by the sarco/endoplasmic reticulum $\mathrm{Ca}^{2+}$-ATPase (SERCA), refilling the ER $\mathrm{Ca}^{2+}$ stores. The prolonged increase in cytosolic $\mathrm{Ca}^{2+}$ concentrations leads to the activation of calcineurin, resulting in the dephosphorylation and nuclear translocation of nuclear factor of activated T cells (NFAT) and subsequent cytokine expression, e.g., interleukin 2 (IL-2), triggering clonal expansion of T cells.

\subsubsection{TRPM7 in Cell Growth, Activation and Development of B Cells}

A Trpm7-deficient B-lymphocyte cell line (chicken DT40 cells) exhibits a selective defect to proliferate in regular media but can do so in media supplemented with $10 \mathrm{mM} \mathrm{Mg}{ }^{2+}$. After $24 \mathrm{~h}$ in regular media, TRPM7-deficient B cells accumulated in the G0/G1 phase of the cell cycle and were reduced in average cell size. Authors conclude that TRPM7-deficient cells display a defect in growth, 
failing to increase in size and mass. This defect was attributed to the lack of signalling downstream of phosphoinositide 3-kinase (PI3-K) with impaired mammalian target of rapamycin complex 1 (mTORC1) signalling, ribosomal S6 kinase (S6K) and Akt activation, whereas ERK phosphorylation was unaltered. Interestingly, overexpression of constitutively active AKT was not sufficient to overcome this growth defect. However, provision of a heterologous sustained PI3K signal, utilizing a constitutively active form of the catalytic subunit of PI3K, p110 $\alpha$, counteracted the failure of TRPM7-deficient cells to grow and proliferate in regular media. Thus TRPM7 was positioned alongside PI3K signalling as a central regulator of lymphocyte growth [77]. Moreover, TRPM7 was shown to be essential for cell-cycle progression, as Trpm7-deficient DT40 B cells showed an up-regulation of p27 $7^{\mathrm{kip}}$, a key cell cycle regulator which blocks the transition from $G_{0}$ to $S$ phase. The quiescence was reversible and rescued by $\mathrm{Mg}^{2+}$ supplementation or TRPM7 overexpression [78]. Utilizing the same Trpm7-deficient DT40 B cell line and a DT40 cell line expressing the kinase-dead mutant (K1648R), it was recently shown that TRPM7 is essential for early events of B cell activation through both kinase and channel activities. TRPM7 channel activity controlled antigen uptake and presentation to T cells [27]. Previously, TRPM7 kinase has been suggested to regulate non-muscle myosin IIA filament stability as well as actomyosin contractility by phosphorylating myosin IIA heavy chain [25], while the $\mathrm{Mg}^{2+}$ influx through the channel was also correlated with maintenance of myosin II-dependent cytoskeletal organization [79]. TIRF microscopy revealed that expression of TRPM7 in B cells controlled actin dynamics and slowed antigen internalization, resulting in prolonged B cell signalling. Authors conclude that TRPM7 signalling is essential for B cell affinity maturation and antibody production [27]. Moreover, recent findings indicate that TRPM7 expression is required for murine B cell development. Mice with tissue specific deletion of TRPM7 in B cells failed to generate peripheral B cells due to a developmental defect at the pro-B cell stage and increased apoptosis of $\mathrm{B}$ cell precursors in the bone marrow. In vitro the development of Trpm7-deficient B cells could be rescued via $\mathrm{Mg}^{2+}$-supplementation. Whereas, TRPM7 kinase-deficiency did not affect the development of B cells in the bone marrow or the percentage of peripheral B cells. Interestingly, the deletion of the entire TRPM7 protein in B cells lead to increased percentages of neutrophils, eosinophils and monocytes in the spleen of mutant mice, compared to WT which could be attributed to the primary lack of B cells [80]. Thus, TRPM7 channel and kinase activities seem unique and non-redundant for proper $B$ cell function.

\subsubsection{TRPM7 in Murine T Cell Development, Differentiation and Transcriptional Regulation}

In murine T lymphocytes TRPM7 is required for thymic development and thymopoiesis. Conditional knock-out of Trpm7 in the $\mathrm{T}$ cell lineage was shown to disrupt thymopoiesis, with thymocytes remaining in the double negative $\left(\mathrm{CD}^{-} \mathrm{CD} 8^{-}\right)$state and resulted in altered chemokine and cytokine expression profiles [28], indicating that TRPM7 channel and/or kinase are important for $\mathrm{T}$ cell function. Using the homozygous kinase-dead $\operatorname{Tr} p m 7^{R / R}$ mouse model, recently it was shown that TRPM7 kinase activity is not essential for thymopoiesis [10,20]. However, the enzymatic activity of TRPM7 is required for intra-epithelial T cell homeostasis. $\operatorname{Tr} p m 7^{R / R}$ mice almost completely lack gut intraepithelial T lymphocytes (IELs) [20]. Intestinal IELs represent a first line of defence within the largest immune organ of our body [81]. Numerous effector T lymphocytes differentiate in the intestine, from where they migrate into the periphery $[82,83]$. Thus, understanding the gut immune system, harbouring $\sim 70 \%$ of the total lymphocytes in the human body, is of utmost importance [81,84] for regulating of immune homeostasis. Analysis of the percentage of remaining $T R P M 7^{R / R}$ IELs revealed a significant reduction in pro-inflammatory $\mathrm{T}_{\mathrm{H}} 17$ cell subsets, while the percentage of anti-inflammatory $\mathrm{T}_{\text {reg }}$ cells was unaffected compared to WT. Consistently, the in vitro differentiation of naïve $\operatorname{Trpm} 7^{R / R} \mathrm{~T}$ cells into $\mathrm{T}_{\mathrm{H}} 17$ cells was also compromised, while the $\mathrm{T}_{\text {reg cell }}$ differentiation proceeded unperturbed. These findings were coherent with the robust reduction of IL-17 concentration in serum from Trpm $7^{R / R}$ mice [20]. As TGF- $\beta /$ SMAD pathways are crucial for the polarization of $\mathrm{CD}^{+} \mathrm{T}$ cells into $\mathrm{T}_{\mathrm{H}} 17$ cells [85], it is likely that the TGF- $\beta$ /SMAD signalling pathway is affected by TRPM7 kinase activity (Figure 3). Notably, Western Blot analysis of $\operatorname{Tr} p m 7^{R / R}$ naïve CD4 ${ }^{+}$ 
T cells treated with TGF- $\beta 1$ revealed a significant reduction in SMAD2 phosphorylation, while SMAD3 phosphorylation was unaltered. Analysis of the TGF- $\beta 1$-induced SMAD2 translocation was also significantly reduced in $\operatorname{Trpm} 7^{R / R}$ naïve $\mathrm{CD} 4^{+} \mathrm{T}$ cells. Thus, authors conclude that the TRPM7 kinase regulates $\mathrm{T}_{\mathrm{H}} 17$ cell differentiation via TGF- $\beta$ /SMAD2 dependent pathways. An in vitro kinase assay using highly purified recombinant TRPM7 kinase, SMAD2, as well as C-terminally truncated SMAD2 revealed that TRPM7 phosphorylates SMAD2 in a dose dependent manner but fails to phosphorylate the truncated SMAD2. Thus, the C-terminal Ser465/467-motif of SMAD2 was identified as a novel substrate for the TRPM7 kinase [20]. The upregulation of the integrin $\alpha \mathrm{E}$, also known as CD103, enables T cells to migrate into the gut epithelium $[86,87]$ and is dependent on SMAD2 TGF- $\beta$ /SMAD2 signalling cascades [88], which was significantly impaired in TGF- $\beta$-treated $\operatorname{Tr} p m 7^{R / R} \mathrm{~T}$ cells. Using a chromatin immunoprecipitation (ChIP) assay, the authors demonstrated a defective binding of SMAD2 to the Itgae (CD103) promoter in $\operatorname{Trpm} 7^{R / R} \mathrm{~T}$ cells in response to TGF- $\beta$. Consequently, the expression of the gene encoding for CD103, Itgae, was also significantly reduced in primary $\operatorname{Trpm} 7^{R / R}$ IELs as well as in response to TGF- $\beta$ and T cell receptor co-stimulation in naïve Trpm $7^{R / R} \mathrm{~T}$ cells. Consistently, the expression of the signature transcription factor for $\mathrm{T}_{\mathrm{H}} 17$ cells, Rorc, as well as the cytokine IL-17, which both depend on SMAD2 phosphorylation and translocation into the nucleus, were also impaired in $\operatorname{Trpm} 7^{R / R} \mathrm{~T}$ cells (Figure 3). Interestingly, the CD103 expression in $\operatorname{Tr} p m 7^{R / R} \mathrm{CD} 11 \mathrm{c}^{+}$dendritic cells was normal, compared to WT [20]. If or how TRPM7 kinase is triggered via TGF- $\beta$ stimulation in T cells is still under investigation. One emerging concept, however, could involve a constitutively active TRPM7 kinase that phosphorylates SMAD2 once it is anchored to the plasma membrane following TGF- $\beta$ receptor activation (Figure 3). Importantly, this selective defect of SMAD2 signalling in T cells culminating in reduced pro-inflammatory $\mathrm{T}_{\mathrm{H}} 17$ cell differentiation, while leaving anti-inflammatory $\mathrm{T}_{\text {reg }}$ cell differentiation unaffected (Figure $4 \mathrm{~A}, \mathrm{~B}$ ), highlights the essential function of TRPM7 kinase in immune homeostasis [20]. These results suggest that TRPM7 kinase might serve as molecular switch from pro-inflammatory to anti-inflammatory milieu and highlights the potential of TRPM7 kinase inhibition for the treatment of pro-inflammatory diseases.

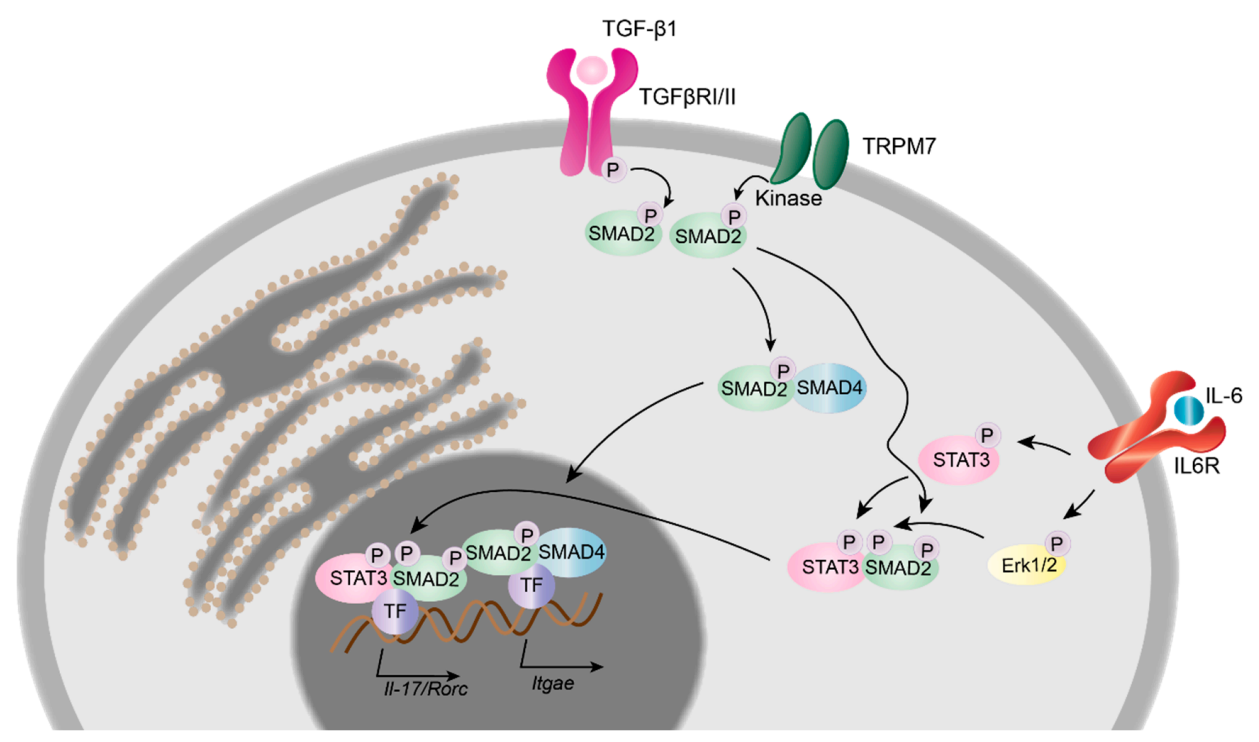

Figure 3. TRPM7 kinase in T cell signalling and transcriptional regulation. Upon binding of tumour growth factor $\beta 1$ (TGF- $\beta 1$ ), the TGF- $\beta$ receptor complex (TGF $\beta$ RI/II) initiates the phosphorylation of the c-terminal SXS-motif of SMAD2. Results gained from TRPM7 kinase deficient murine T cells suggest an additional mechanism by which the TRPM7 kinase phosphorylates SMAD2 directly, once it is anchored to the plasma membrane. Phosphorylated SMAD2 interacts with SMAD4 and promotes the transcription of Itgae, Il-17 and Rorc genes. The interleukin 6 (IL-6) dependent STAT3 as well as Erk1/2 phosphorylation pathway is unaltered in TRPM7 kinase deficient murine T cells. 
To date, very little is known regarding the role of TRPM7 in human lymphocytes. Pharmacological inhibition of TRPM7 in a human T cell line results in growth arrest and reduced proliferation [89]. TRPM7 was suggested to be involved in the migration of activated human T cells, where it is located in the uropod, in conjunction with the calcium-activated potassium channel, $\mathrm{K}_{\mathrm{Ca}} 3.1$, facilitating $\mathrm{T}$ cell migration. Knock-down via siRNA resulted in a significant reduction in number and velocity of migrating cells [90]. Moreover, TRPM7 was associated with TNF- $\alpha$-induced necroptosis in T cells. Knock-down of TRPM7 in a T cell line protected it from necroptosis [91]. Nonetheless, it will be necessary to determine if the observed crucial functions of TRPM7 kinase and channel moieties in murine lymphocytes also applies to human counterparts.

A

$$
\begin{aligned}
& \text { T cell } \\
& \text { differentiation }
\end{aligned}
$$

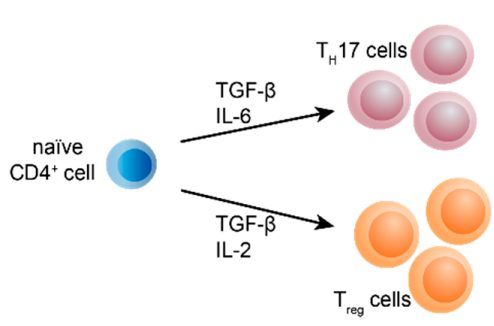

C

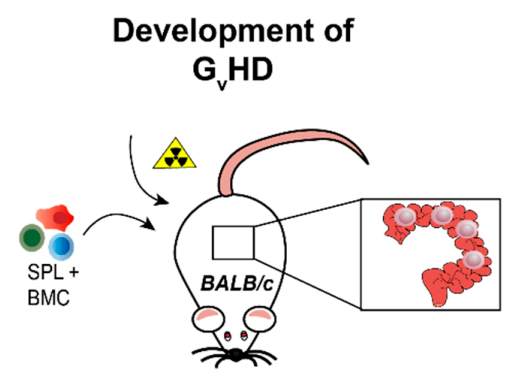

B

TRPM7 kinase inhibition

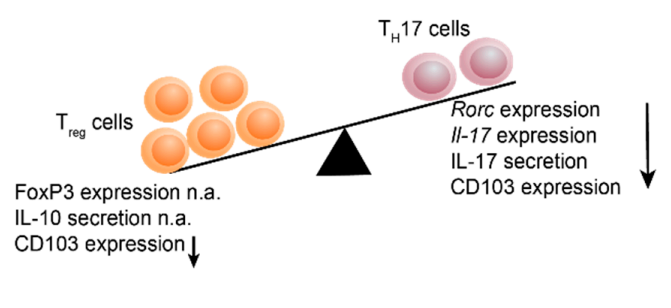

Protection from G $\mathrm{HD}$

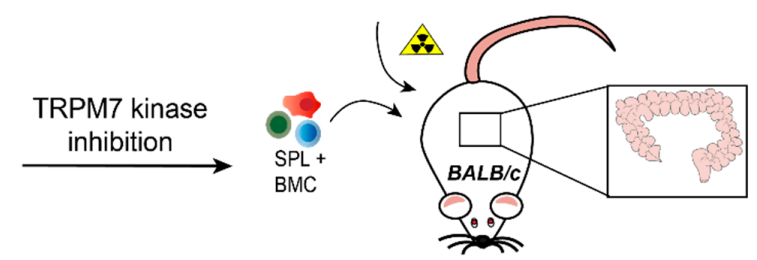

Figure 4. TRPM7 kinase is essential for $\mathrm{T}$ cell differentiation into the pro-inflammatory $\mathrm{T}_{\mathrm{H}} 17$ cell type and the development of graft versus host disease. (A) Naïve $\mathrm{CD} 4^{+} \mathrm{T}$ cells differentiate into pro-inflammatory $\mathrm{T}_{\mathrm{H}} 17$ cells in the presence of TGF- $\beta$ and IL- 6 . For the differentiation into anti-inflammatory regulatory T cells ( $\mathrm{T}_{\text {regs }}$ ), the cytokines TGF- $\beta$ and IL-2 are required. (B) Genetic inactivation of TRPM7 kinase activity $\left(\operatorname{Trpm} 7^{R / R}\right)$ results in reduced $\mathrm{T}_{\mathrm{H}} 17$ cell differentiation, indicated via diminished Rorc and Il-17 mRNA expression as well as IL-17 serum levels, while $\mathrm{T}_{\text {reg }}$ cell differentiation, evident via FoxP3 expression and IL-10 serum levels, is unaltered. In addition, integrin $\alpha \mathrm{E}$ (CD103) expression is reduced in TRPM7 kinase deficient $\mathrm{T}$ cells. (C) Transplantation of bone marrow cells (BMC, C57BL/6) in conjunction with splenocytes (SPL, C57BL/6) triggers the development of graft versus host disease $\left(G_{V} H D\right)$ in lethally irradiated mice with different genetic background (BALB/c), manifesting in massive tissue destruction of the intestine but also lung and skin tissues. TRPM7 kinase deficient BMC and SPL transplantation does not induce inflammation in the intestine and ameliorates or even prevents disease progression, suggesting TRPM7 kinase inhibition as valid tool for the treatment of $G_{V} H D$. n.a. (not altered).

\section{TRPM7-Mediated Hematologic and Inflammatory Diseases}

\subsection{Hypomagnesaemia and TRPM7 Kinase in Delayed-Type Hypersensitivity Reactions}

$\mathrm{Mg}^{2+}$ is a vital mineral macronutrient. Considering that low serum $\mathrm{Mg}^{2+}$ levels have also been linked to memory decline, neurodegenerative diseases, decrease in muscle performance, heart failure, certain cancers, autoimmune diseases and allergic reactions, it is of critical importance to further identify the mechanisms regulating the availability of this macronutrient $[92,93]$. Recently, it was 
shown that TRPM7, in conjunction with its sister channel TRPM6, regulates systemic $\mathrm{Mg}^{2+}$ homeostasis via absorption of $\mathrm{Mg}^{2+}$ in the intestine [94]. The interconnection between nutrient metabolism and the immune system occurs at many levels, ranging from endocrine signalling to direct sensing of nutrients by immune cells [95]. Interestingly, adult Trpm6-deficient mice suffered from hypomagnesaemia and displayed a degeneration of many lymphoid organs. The thymus of mutant mice was only rudimentary present with an essentially undistinguishable cortex region. Also, the red pulp of the spleens of Trpm6-deficient mice was substantially reduced. Dietary $\mathrm{Mg}^{2+}$ supplementation rescued these phenotypes, indicating that indeed hypomagnesaemia was responsible for the observed deficits [94].

While homozygous genetic deletion of the ubiquitously expressed TRPM7 kinase domain in mice leads to early embryonic lethality, heterozygous $\operatorname{Tr} m 7^{+/ \Delta k}$ mice are viable and develop a severe hypomagnesaemia upon $\mathrm{Mg}^{2+}$ restriction, leading to increased mortality, susceptibility to seizures as well as prevalence for allergic hypersensitivity [4]. It is known that low, systemic $\mathrm{Mg}^{2+}$ levels correlate with cell-extrinsic enhancement of systemic inflammatory and allergic responses [96]. To evaluate the level of delayed-type hypersensitivity responses in $\operatorname{Trpm} 7^{+/ \Delta k}$ mice, oxazolone sensitization experiments were performed. $\operatorname{Tr} p m 7^{+/ \Delta k}$ mice displayed an elevated oxazolone-induced contact hypersensitivity, compared to WT [4]. Interestingly, homozygous mice with genetic inactivation of TRPM7 kinase activity, via a point mutation within the active site of the kinase, $\operatorname{Tr} p m 7^{R / R}$, were viable and did not develop hypomagnesaemia or hypersensitivity responses. In fact, they even displayed reduced oxazolone-induced delayed type hypersensitivity responses [30]. Their systemic $\mathrm{Mg}^{2+}$ and $\mathrm{Ca}^{2+}$ levels were similar to WT, as the channel function was not affected by the point mutation [29,30,32]. Since allergic reactions are triggered by mast cell-mediated histamine release, the role of TRPM7 in mast cell degranulation and histamine release was studied using $\operatorname{Trp} m 7^{+/+}, \operatorname{Tr} p m 7^{+/ \Delta k}$ and $\operatorname{Trpm} 7^{R / R}$ mice. As reported, degranulation and histamine release proceeded independently of TRPM7 channel function. However, as extracellular $\mathrm{Mg}^{2+}$ was essential to control unperturbed IgE-DNP-dependent exocytosis and removal of $\mathrm{Mg}^{2+}$ exaggerated histamine release, the observed differences in hypersensitivity responses could be attributed to the different systemic $\mathrm{Mg}^{2+}$ levels in $\operatorname{Tr} p m 7^{+/ \Delta k}$ versus $\operatorname{Trpm} 7^{R / R}$ mice. G-protein-coupled receptor stimulation revealed strong suppression of histamine release in both kinase-deficient mast cells $\left(\operatorname{Trpm} 7^{+/ \Delta k}\right.$ and $\operatorname{Trpm} 7^{R / R}$ ), whereas removal of extracellular $\mathrm{Mg}^{2+}$ caused the phenotype to revert, suggesting that the TRPM7 kinase activity regulates murine mast cell degranulation by changing its sensitivity to intracellular $\mathrm{Ca}^{2+}$ and extracellular $\mathrm{Mg}^{2+}$ concentrations [32] Thus, TRPM7 might inflict its immune-modulatory role by sensing cations via its kinase domain. To date, little is known about activation mechanisms or physiologic substrates of TRPM7 kinase.

\subsection{The TRPM7 Channel-Kinase in Arterial Thrombosis and Stroke}

TRPM7 kinase has been suggested to regulate myosin IIB filament stability as well as actomyosin contractility by phosphorylating myosin IIA [25]. Recently, it was shown that TRPM7 channel activity also affects myosin IIA activity independently of kinase function. In conditional Trpm7-deficient mice (Trpm 7 fl/fl-Pf4Cre $)$, TRPM7 modulates platelet function via regulation of cellular $\mathrm{Mg}^{2+}$ homeostasis and cytoskeletal myosin IIA activity. Members of a human pedigree with mutations in TRPM7 (p.C721G), causing disrupted channel activity, suffer from macrothrombocytopenia and arterial fibrosis. The defect in platelet biogenesis is mainly caused by cytoskeletal alterations resulting in impaired pro-platelet formation by TRPM7-deficient megakaryocytes, which is rescued by $\mathrm{Mg}^{2+}$ supplementation [79]. In contrast, homozygous kinase-dead TRPM ${ }^{R / R}$ mice show normal platelet counts, size and morphology, thus suggesting that the lack of TRPM7 channel rather than its kinase

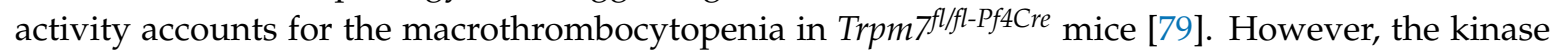
controls platelet function in arterial thrombosis via regulation of $\mathrm{Ca}^{2+}$ responses, Syk and PLC $\gamma 2$ activity. Bone marrow (BM) chimeras revealed that the kinase is not only relevant for platelet function, as both, recipients of WT BM as well as WT recipient of $\operatorname{Trpm} 7^{R / R} \mathrm{BM}$, developed reduction in infarct size and improvement of neurological and motoric functions in an in vivo transient middle cerebral artery occlusion (tMCAO) model. Thus, TRPM7 kinase activity in neurons and glial cells may also be 
critical for the progression of ischemic brain infarction [11]. These findings highlight TRPM7 kinase as a potential target for the treatment of thrombosis thus protecting from stroke or myocardial infarction.

\subsection{TRPM7 Kinase Signalling Supports Graft versus Host Reactions}

Graft versus host disease $\left(\mathrm{G}_{\mathrm{V}} \mathrm{HD}\right)$ is the most common side effect of an allogeneic hematopoietic stem cell transplantation (HCST). In this immune reaction the donor $\mathrm{T}$ cells recognize the patients human leukocyte antigen (HLA) as foreign, causing an inflammatory cascade [97]. GVHD can be divided into acute and chronic, depending on the time of diagnosis [98]. In acute $\mathrm{G}_{\mathrm{V}} \mathrm{HD}$ the pre-transplant radiation may cause tissue damage in the host, leading to the activation of antigen presenting cells followed by activation of the donor $\mathrm{T}$ cells. This can lead to severe damage of liver, skin, mucosa and the gastrointestinal tract [99]. All in all, $\mathrm{G}_{\mathrm{V}} \mathrm{HD}$ causes $15-30 \%$ of death after HCST, highlighting the importance of enhancing the understanding of this disease and finding improved treatments. Recently, it was shown that TRPM7 kinase activity promotes gut colonization by T cells in acute $\mathrm{G}_{\mathrm{V}} \mathrm{HD}$. During this process, naïve donor $\mathrm{CD} 4^{+} \mathrm{T}$ cells recognize alloantigens on antigen presenting cells in target organs, including the intestine (Figure 4C).

The role of different $T_{H}$ subsets and signalling pathways in the pathogenesis of $G_{V} H D$ is incompletely understood. To address whether defective intestinal colonization by $\mathrm{CD} 4^{+} \mathrm{T}$ cells lacking TRPM7 kinase activity could affect acute $\mathrm{G}_{\mathrm{V}} \mathrm{HD}$, the bone marrow (BM) of BALB/c WT mice was lethally irradiated and replaced by bone marrow (BM) cells from WT C57BL/ 6 mice together with WT or $T R P M 7^{R / R}$ splenocytes. As expected, injection of WT splenocytes resulted in massive intestinal damage and most mice died within 35 days after transplantation. In contrast, injection of $T R P M 7^{R / R}$ splenocytes did not cause intestinal damage and resulted in a dramatically increased survival of these mice within the first 60 days after transplantation [20]. These results unravel a fundamental role of TRPM7 kinase in $\mathrm{T}$ cell function and suggest a therapeutic potential of kinase inhibitors in averting acute $\mathrm{G}_{\mathrm{V}} \mathrm{HD}$.

\section{Conclusions}

The involvement of TRPM7 in the pathogenesis of deregulated immune responses highlights the necessity for novel pharmacological tools. TRPM7 represents a new promising drug target for the treatment of pro-inflammatory diseases and hypersensitivity. It is tempting to speculate that pharmacological modulation of TRPM7 may reinstate immune system homeostasis. Particularly appealing is the fact that TRPM7 kinase-deficiency in mice does not result in an obvious phenotype and only moderately affects haemostasis. Thus, TRPM7 kinase inhibition should not cause major side effects. Therefore, new TRPM7 kinase inhibitors and novel kinase substrates have to be identified.

Author Contributions: W.N. performed literature search, wrote sections of the original draft, prepared the figures and edited the manuscript. S.Z. wrote the original draft, designed the figures and edited the manuscript.

Funding: S.Z. was supported by the Deutsche Forschungsgemeinschaft (TRR 152) and a Marie-Curie Fellowship (REA) FP7-PEOPLE-2012-CIG.

Acknowledgments: We thank Lynda Addington for critical reading of the manuscript. Images were designed using Adobe Illustrator CC.

Conflicts of Interest: The authors declare no conflict of interest.

\section{References}

1. Nadler, M.J.; Hermosura, M.C.; Inabe, K.; Perraud, A.L.; Zhu, Q.; Stokes, A.J.; Kurosaki, T.; Kinet, J.P.; Penner, R.; Scharenberg, A.M.; et al. LTRPC7 is a Mg.ATP-regulated divalent cation channel required for cell viability. Nature 2001, 411, 590-595. [CrossRef] [PubMed]

2. Monteilh-Zoller, M.K.; Hermosura, M.C.; Nadler, M.J.; Scharenberg, A.M.; Penner, R.; Fleig, A. TRPM7 provides an ion channel mechanism for cellular entry of trace metal ions. J. Gen. Physiol. 2003, 121, 49-60. [CrossRef] [PubMed] 
3. Runnels, L.W.; Yue, L.; Clapham, D.E. TRP-PLIK, a bifunctional protein with kinase and ion channel activities. Science 2001, 291, 1043-1047. [CrossRef] [PubMed]

4. Ryazanova, L.V.; Rondon, L.J.; Zierler, S.; Hu, Z.; Galli, J.; Yamaguchi, T.P.; Mazur, A.; Fleig, A.; Ryazanov, A.G. TRPM7 is essential for $\mathrm{Mg}^{2+}$ homeostasis in mammals. Nat. Commun. 2010, 1, 109. [CrossRef] [PubMed]

5. Schmitz, C.; Perraud, A.L.; Johnson, C.O.; Inabe, K.; Smith, M.K.; Penner, R.; Kurosaki, T.; Fleig, A.; Scharenberg, A.M. Regulation of vertebrate cellular $\mathrm{Mg}^{2+}$ homeostasis by TRPM7. Cell 2003, 114, 191-200. [CrossRef]

6. He, Y.; Yao, G.; Savoia, C.; Touyz, R.M. Transient receptor potential melastatin 7 ion channels regulate magnesium homeostasis in vascular smooth muscle cells: Role of angiotensin II. Circ. Res. 2005, 96, 207-215. [CrossRef] [PubMed]

7. Abiria, S.A.; Krapivinsky, G.; Sah, R.; Santa-Cruz, A.G.; Chaudhuri, D.; Zhang, J.; Adstamongkonkul, P.; DeCaen, P.G.; Clapham, D.E. TRPM7 senses oxidative stress to release $\mathrm{Zn}^{2+}$ from unique intracellular vesicles. Proc. Natl. Acad. Sci. USA 2017, 114, E6079-E6088. [CrossRef] [PubMed]

8. Inoue, K.; Branigan, D.; Xiong, Z.G. Zinc-induced neurotoxicity mediated by transient receptor potential melastatin 7 channels. J. Biol. Chem. 2010, 285, 7430-7439. [CrossRef] [PubMed]

9. Suzuki, S.; Lis, A.; Schmitz, C.; Penner, R.; Fleig, A. The TRPM7 kinase limits receptor-induced calcium release by regulating heterotrimeric G-proteins. Cell. Mol. Life Sci. 2018, 75, 3069-3078. [CrossRef] [PubMed]

10. Beesetty, P.; Wieczerzak, K.B.; Gibson, J.N.; Kaitsuka, T.; Luu, C.T.; Matsushita, M.; Kozak, J.A. Inactivation of TRPM7 kinase in mice results in enlarged spleens, reduced T-cell proliferation and diminished store-operated calcium entry. Sci. Rep. 2018, 8, 3023. [CrossRef] [PubMed]

11. Gotru, S.K.; Chen, W.; Kraft, P.; Becker, I.C.; Wolf, K.; Stritt, S.; Zierler, S.; Hermanns, H.M.; Rao, D.; Perraud, A.L.; et al. TRPM7 Kinase Controls Calcium Responses in Arterial Thrombosis and Stroke in Mice. Arterioscler. Thromb. Vasc. Biol. 2018, 38, 344-352. [CrossRef] [PubMed]

12. Faouzi, M.; Kilch, T.; Horgen, F.D.; Fleig, A.; Penner, R. The TRPM7 channel kinase regulates store-operated calcium entry. J. Physiol. 2017, 595, 3165-3180. [CrossRef] [PubMed]

13. Demeuse, P.; Penner, R.; Fleig, A. TRPM7 channel is regulated by magnesium nucleotides via its kinase domain. J. Gen. Physiol. 2006, 127, 421-434. [CrossRef] [PubMed]

14. Kozak, J.A.; Matsushita, M.; Nairn, A.C.; Cahalan, M.D. Charge screening by internal pH and polyvalent cations as a mechanism for activation, inhibition, and rundown of TRPM7/MIC channels. J. Gen. Physiol. 2005, 126, 499-514. [CrossRef] [PubMed]

15. Runnels, L.W.; Yue, L.; Clapham, D.E. The TRPM7 channel is inactivated by PIP 2 hydrolysis. Nat. Cell Biol. 2002, 4, 329-336. [CrossRef] [PubMed]

16. Yu, H.; Zhang, Z.; Lis, A.; Penner, R.; Fleig, A. TRPM7 is regulated by halides through its kinase domain. Cell. Mol. Life Sci. 2013, 70, 2757-2771. [CrossRef] [PubMed]

17. Romani, A.M. Cellular magnesium homeostasis. Arch. Biochem. Biophys. 2011, 512, 1-23. [CrossRef] [PubMed]

18. Chubanov, V.; Ferioli, S.; Gudermann, T. Assessment of TRPM7 functions by drug-like small molecules. Cell Calcium 2017, 67, 166-173. [CrossRef] [PubMed]

19. Ferioli, S.; Zierler, S.; Zaisserer, J.; Schredelseker, J.; Gudermann, T.; Chubanov, V. TRPM6 and TRPM7 differentially contribute to the relief of heteromeric TRPM6/7 channels from inhibition by cytosolic $\mathrm{Mg}^{2+}$ and Mg.ATP. Sci. Rep. 2017, 7, 8806. [CrossRef] [PubMed]

20. Romagnani, A.; Vettore, V.; Rezzonico-Jost, T.; Hampe, S.; Rottoli, E.; Nadolni, W.; Perotti, M.; Meier, M.A.; Hermanns, C.; Geiger, S.; et al. TRPM7 kinase activity is essential for T cell colonization and alloreactivity in the gut. Nat. Commun. 2017, 8, 1917. [CrossRef] [PubMed]

21. Yamaguchi, H.; Matsushita, M.; Nairn, A.C.; Kuriyan, J. Crystal structure of the atypical protein kinase domain of a TRP channel with phosphotransferase activity. Mol. Cell 2001, 7, 1047-1057. [CrossRef]

22. Ryazanova, L.V.; Dorovkov, M.V.; Ansari, A.; Ryazanov, A.G. Characterization of the protein kinase activity of TRPM7/ChaK1, a protein kinase fused to the transient receptor potential ion channel. J. Biol. Chem. 2004, 279, 3708-3716. [CrossRef] [PubMed]

23. Dorovkov, M.V.; Ryazanov, A.G. Phosphorylation of annexin I by TRPM7 channel-kinase. J. Biol. Chem. 2004, 279, 50643-50646. [CrossRef] [PubMed]

24. Dorovkov, M.V.; Kostyukova, A.S.; Ryazanov, A.G. Phosphorylation of annexin A1 by TRPM7 kinase: A switch regulating the induction of an alpha-helix. Biochemistry 2011, 50, 2187-2193. [CrossRef] [PubMed] 
25. Clark, K.; Middelbeek, J.; Dorovkov, M.V.; Figdor, C.G.; Ryazanov, A.G.; Lasonder, E.; van Leeuwen, F.N. The alpha-kinases TRPM6 and TRPM7, but not eEF-2 kinase, phosphorylate the assembly domain of myosin IIA, IIB and IIC. FEBS Lett. 2008, 582, 2993-2997. [CrossRef] [PubMed]

26. Deason-Towne, F.; Perraud, A.L.; Schmitz, C. Identification of Ser/Thr phosphorylation sites in the C2-domain of phospholipase C $\gamma 2$ (PLC $\gamma 2$ ) using TRPM7-kinase. Cell Signal. 2012, 24, 2070-2075. [CrossRef] [PubMed]

27. Krishnamoorthy, M.; Wasim, L.; Buhari, F.H.M.; Zhao, T.; Mahtani, T.; Ho, J.; Kang, S.; Deason-Towne, F.; Perraud, A.L.; Schmitz, C.; et al. The channel-kinase TRPM7 regulates antigen gathering and internalization in B cells. Sci. Signal. 2018, 11, eaah6692. [CrossRef] [PubMed]

28. Jin, J.; Desai, B.N.; Navarro, B.; Donovan, A.; Andrews, N.C.; Clapham, D.E. Deletion of Trpm7 disrupts embryonic development and thymopoiesis without altering $\mathrm{Mg}^{2+}$ homeostasis. Science 2008, 322, 756-760. [CrossRef] [PubMed]

29. Kaitsuka, T.; Katagiri, C.; Beesetty, P.; Nakamura, K.; Hourani, S.; Tomizawa, K.; Kozak, J.A.; Matsushita, M. Inactivation of TRPM7 kinase activity does not impair its channel function in mice. Sci. Rep. 2014, 4, 5718. [CrossRef] [PubMed]

30. Ryazanova, L.V.; Hu, Z.; Suzuki, S.; Chubanov, V.; Fleig, A.; Ryazanov, A.G. Elucidating the role of the TRPM7 alpha-kinase: TRPM7 kinase inactivation leads to magnesium deprivation resistance phenotype in mice. Sci. Rep. 2014, 4, 7599. [CrossRef] [PubMed]

31. Desai, B.N.; Krapivinsky, G.; Navarro, B.; Krapivinsky, L.; Carter, B.C.; Febvay, S.; Delling, M.; Penumaka, A.; Ramsey, I.S.; Manasian, Y.; et al. Cleavage of TRPM7 releases the kinase domain from the ion channel and regulates its participation in Fas-induced apoptosis. Dev. Cell 2012, 22, 1149-1162. [CrossRef] [PubMed]

32. Zierler, S.; Sumoza-Toledo, A.; Suzuki, S.; Duill, F.O.; Ryazanova, L.V.; Penner, R.; Ryazanov, A.G.; Fleig, A. TRPM7 kinase activity regulates murine mast cell degranulation. J. Physiol. 2016, 594, 2957-2970. [CrossRef] [PubMed]

33. Kim, T.Y.; Shin, S.K.; Song, M.Y.; Lee, J.E.; Park, K.S. Identification of the phosphorylation sites on intact TRPM7 channels from mammalian cells. Biochem. Biophys. Res. Commun. 2012, 417, 1030-1034. [CrossRef] [PubMed]

34. Clark, K.; Middelbeek, J.; Morrice, N.A.; Figdor, C.G.; Lasonder, E.; van Leeuwen, F.N. Massive autophosphorylation of the Ser/Thr-rich domain controls protein kinase activity of TRPM6 and TRPM7. PLoS ONE 2008, 3, e1876. [CrossRef] [PubMed]

35. Brandao, K.; Deason-Towne, F.; Zhao, X.; Perraud, A.L.; Schmitz, C. TRPM6 kinase activity regulates TRPM7 trafficking and inhibits cellular growth under hypomagnesic conditions. Cell. Mol. Life Sci. 2014, 71, 4853-4867. [CrossRef] [PubMed]

36. Cai, N.; Bai, Z.; Nanda, V.; Runnels, L.W. Mass Spectrometric Analysis of TRPM6 and TRPM7 Phosphorylation Reveals Regulatory Mechanisms of the Channel-Kinases. Sci. Rep. 2017, 7, 42739. [CrossRef] [PubMed]

37. Fonfria, E.; Murdock, P.R.; Cusdin, F.S.; Benham, C.D.; Kelsell, R.E.; McNulty, S. Tissue distribution profiles of the human TRPM cation channel family. J. Recept. Signal Transduct. 2006, 26, 159-178. [CrossRef] [PubMed]

38. Zierler, S.; Hampe, S.; Nadolni, W. TRPM channels as potential therapeutic targets against pro-inflammatory diseases. Cell Calcium 2017, 67, 105-115. [CrossRef] [PubMed]

39. Schappe, M.S.; Szteyn, K.; Stremska, M.E.; Mendu, S.K.; Downs, T.K.; Seegren, P.V.; Mahoney, M.A.; Dixit, S.; Krupa, J.K.; Stipes, E.J.; et al. Chanzyme TRPM7 Mediates the $\mathrm{Ca}^{2+}$ Influx Essential for Lipopolysaccharide-Induced Toll-Like Receptor 4 Endocytosis and Macrophage Activation. Immunity 2018, 48, 59-74. [CrossRef] [PubMed]

40. Siebenhaar, F.; Redegeld, F.A.; Bischoff, S.C.; Gibbs, B.F.; Maurer, M. Mast Cells as Drivers of Disease and Therapeutic Targets. Trends Immunol. 2017, 39, 151-162. [CrossRef] [PubMed]

41. Kempuraj, D.; Selvakumar, G.P.; Thangavel, R.; Ahmed, M.E.; Zaheer, S.; Raikwar, S.P.; Iyer, S.S.; Bhagavan, S.M.; Beladakere-Ramaswamy, S.; Zaheer, A. Mast Cell Activation in Brain Injury, Stress, and Post-traumatic Stress Disorder and Alzheimer's Disease Pathogenesis. Front. Neurosci. 2017, 11, 703. [CrossRef] [PubMed]

42. Skaper, S.D.; Facci, L.; Zusso, M.; Giusti, P. Neuroinflammation, Mast Cells, and Glia: Dangerous Liaisons. Neuroscientist 2017, 23, 478-498. [CrossRef] [PubMed] 
43. Lindstedt, K.A.; Kovanen, P.T. Isolation of mast cell granules. Curr. Protoc. Cell Biol. 2006, 29, 3-16. [CrossRef] [PubMed]

44. Bulfone-Paus, S.; Nilsson, G.; Draber, P.; Blank, U.; Levi-Schaffer, F. Positive and Negative Signals in Mast Cell Activation. Trends Immunol. 2017, 38, 657-667. [CrossRef] [PubMed]

45. Evans, D.P.; Thomson, D.S. Histamine release from rat mast cells passively sensitised with homocytotropic (IgE) antibody. Int. Arch. Allergy Appl. Immunol. 1972, 43, 217-231. [CrossRef] [PubMed]

46. Chen, Y.C.; Chang, Y.C.; Chang, H.A.; Lin, Y.S.; Tsao, C.W.; Shen, M.R.; Chiu, W.T. Differential Ca ${ }^{2+}$ mobilization and mast cell degranulation by FcepsilonRI- and GPCR-mediated signaling. Cell Calcium 2017, 67, 31-39. [CrossRef] [PubMed]

47. Gaudenzio, N.; Sibilano, R.; Marichal, T.; Starkl, P.; Reber, L.L.; Cenac, N.; McNeil, B.D.; Dong, X.; Hernandez, J.D.; Sagi-Eisenberg, R.; et al. Different activation signals induce distinct mast cell degranulation strategies. J. Clin. Investig. 2016, 126, 3981-3998. [CrossRef] [PubMed]

48. Baba, Y.; Nishida, K.; Fujii, Y.; Hirano, T.; Hikida, M.; Kurosaki, T. Essential function for the calcium sensor STIM1 in mast cell activation and anaphylactic responses. Nat. Immunol. 2008, 9, 81-88. [CrossRef] [PubMed]

49. Vig, M.; DeHaven, W.I.; Bird, G.S.; Billingsley, J.M.; Wang, H.; Rao, P.E.; Hutchings, A.B.; Jouvin, M.H.; Putney, J.W.; Kinet, J.P. Defective mast cell effector functions in mice lacking the CRACM1 pore subunit of store-operated calcium release-activated calcium channels. Nat. Immunol. 2008, 9, 89-96. [CrossRef] [PubMed]

50. Wykes, R.C.; Lee, M.; Duffy, S.M.; Yang, W.; Seward, E.P.; Bradding, P. Functional transient receptor potential melastatin 7 channels are critical for human mast cell survival. J. Immunol. 2007, 179, 4045-4052. [CrossRef] [PubMed]

51. Huang, L.; Ng, N.M.; Chen, M.; Lin, X.; Tang, T.; Cheng, H.; Yang, C.; Jiang, S. Inhibition of TRPM7 channels reduces degranulation and release of cytokines in rat bone marrow-derived mast cells. Int. J. Mol. Sci. 2014, 15, 11817-11831. [CrossRef] [PubMed]

52. DeHaven, W.I.; Smyth, J.T.; Boyles, R.R.; Bird, G.S.; Putney, J.W., Jr. Complex actions of 2-aminoethyldiphenyl borate on store-operated calcium entry. J. Biol. Chem. 2008, 283, 19265-19273. [CrossRef] [PubMed]

53. Amulic, B.; Cazalet, C.; Hayes, G.L.; Metzler, K.D.; Zychlinsky, A. Neutrophil function: From mechanisms to disease. Annu. Rev. Immunol. 2012, 30, 459-489. [CrossRef] [PubMed]

54. Dixit, N.; Simon, S.I. Chemokines, selectins and intracellular calcium flux: Temporal and spatial cues for leukocyte arrest. Front. Immunol. 2012, 3, 188. [CrossRef] [PubMed]

55. Immler, R.; Simon, S.I.; Sperandio, M. Calcium signalling and related ion channels in neutrophil recruitment and function. Eur. J. Clin. Investig. 2018, e12964. [CrossRef] [PubMed]

56. Abed, E.; Moreau, R. Importance of melastatin-like transient receptor potential 7 and magnesium in the stimulation of osteoblast proliferation and migration by PDGF. Am. J. Physiol. Cell Physiol. 2009, 297, C360-C368. [CrossRef] [PubMed]

57. Chen, J.P.; Luan, Y.; You, C.X.; Chen, X.H.; Luo, R.C.; Li, R. TRPM7 regulates the migration of human nasopharyngeal carcinoma cell by mediating $\mathrm{Ca}^{2+}$ influx. Cell Calcium 2010, 47, 425-432. [CrossRef] [PubMed]

58. Wei, C.; Wang, X.; Chen, M.; Ouyang, K.; Song, L.S.; Cheng, H. Calcium flickers steer cell migration. Nature 2009, 457, 901-905. [CrossRef] [PubMed]

59. Wang, C.H.; Rong, M.Y.; Wang, L.; Ren, Z.; Chen, L.N.; Jia, J.F.; Li, X.Y.; Wu, Z.B.; Chen, Z.N.; Zhu, P. CD147 up-regulates calcium-induced chemotaxis, adhesion ability and invasiveness of human neutrophils via a TRPM-7-mediated mechanism. Rheumatology 2014, 53, 2288-2296. [CrossRef] [PubMed]

60. Johnson, E.R.; Matthay, M.A. Acute lung injury: Epidemiology, pathogenesis, and treatment. J. Aerosol Med. Pulm. Drug Deliv. 2010, 23, 243-252. [CrossRef] [PubMed]

61. Yang, C.W.; Liu, H.; Li, X.D.; Sui, S.G.; Liu, Y.F. Salvianolic acid B protects against acute lung injury by decreasing TRPM6 and TRPM7 expressions in a rat model of sepsis. J. Cell. Biochem. 2018, 119, 701-711. [CrossRef] [PubMed]

62. Iwasaki, A.; Medzhitov, R. Control of adaptive immunity by the innate immune system. Nat. Immunol. 2015, 16, 343-353. [CrossRef] [PubMed]

63. Varol, C.; Mildner, A.; Jung, S. Macrophages: Development and tissue specialization. Annu. Rev. Immunol. 2015, 33, 643-675. [CrossRef] [PubMed] 
64. Santoni, G.; Morelli, M.B.; Amantini, C.; Santoni, M.; Nabissi, M.; Marinelli, O.; Santoni, A. “Immuno-Transient Receptor Potential Ion Channels": The Role in Monocyte- and Macrophage-Mediated Inflammatory Responses. Front. Immunol. 2018, 9, 1273. [CrossRef] [PubMed]

65. Lee, Y.K.; Im, Y.J.; Kim, Y.L.; Im, D.S. Characterization of $\mathrm{Ca}^{2+}$ influx induced by dimethylphytosphingosine and lysophosphatidylcholine in U937 monocytes. Biochem. Biophys. Res. Commun. 2006, 348, 1116-1122. [CrossRef] [PubMed]

66. Wuensch, T.; Thilo, F.; Krueger, K.; Scholze, A.; Ristow, M.; Tepel, M. High glucose-induced oxidative stress increases transient receptor potential channel expression in human monocytes. Diabetes 2010, 59, 844-849. [CrossRef] [PubMed]

67. Li, Y.; Jiang, H.; Ruan, C.; Zhong, J.; Gao, P.; Zhu, D.; Niu, W.; Guo, S. The interaction of transient receptor potential melastatin 7 with macrophages promotes vascular adventitial remodeling in transverse aortic constriction rats. Hypertens. Res. 2014, 37, 35-42. [CrossRef] [PubMed]

68. Schilling, T.; Miralles, F.; Eder, C. TRPM7 regulates proliferation and polarisation of macrophages. J. Cell Sci. 2014, 127, 4561-4566. [CrossRef] [PubMed]

69. Murray, P.J.; Wynn, T.A. Protective and pathogenic functions of macrophage subsets. Nat. Rev. Immunol. 2011, 11, 723-737. [CrossRef] [PubMed]

70. Martinez, F.O.; Helming, L.; Gordon, S. Alternative activation of macrophages: An immunologic functional perspective. Annu. Rev. Immunol. 2009, 27, 451-483. [CrossRef] [PubMed]

71. Chubanov, V.; Mederos y Schnitzler, M.; Meissner, M.; Schafer, S.; Abstiens, K.; Hofmann, T.; Gudermann, T. Natural and synthetic modulators of SK (Kca2) potassium channels inhibit magnesium-dependent activity of the kinase-coupled cation channel TRPM7. Br. J. Pharmacol. 2012, 166, 1357-1376. [CrossRef] [PubMed]

72. Vaeth, M.; Zee, I.; Concepcion, A.R.; Maus, M.; Shaw, P.; Portal-Celhay, C.; Zahra, A.; Kozhaya, L.; Weidinger, C.; Philips, J.; et al. $\mathrm{Ca}^{2+}$ Signaling but Not Store-Operated $\mathrm{Ca}^{2+}$ Entry Is Required for the Function of Macrophages and Dendritic Cells. J. Immunol. 2015, 195, 1202-1217. [CrossRef] [PubMed]

73. Haslberger, A.; Romanin, C.; Koerber, R. Membrane potential modulates release of tumor necrosis factor in lipopolysaccharide-stimulated mouse macrophages. Mol. Biol. Cell 1992, 3, 451-460. [CrossRef] [PubMed]

74. Yatim, K.M.; Lakkis, F.G. A brief journey through the immune system. Clin. J. Am. Soc. Nephrol. 2015, 10, 1274-1281. [CrossRef] [PubMed]

75. Heinzel, S.; Marchingo, J.M.; Horton, M.B.; Hodgkin, P.D. The regulation of lymphocyte activation and proliferation. Curr. Opin. Immunol. 2018, 51, 32-38. [CrossRef] [PubMed]

76. Matsushita, M.; Kozak, J.A.; Shimizu, Y.; McLachlin, D.T.; Yamaguchi, H.; Wei, F.Y.; Tomizawa, K.; Matsui, H.; Chait, B.T.; Cahalan, M.D.; et al. Channel function is dissociated from the intrinsic kinase activity and autophosphorylation of TRPM7/ChaK1. J. Biol. Chem. 2005, 280, 20793-20803. [CrossRef] [PubMed]

77. Sahni, J.; Scharenberg, A.M. TRPM7 ion channels are required for sustained phosphoinositide 3-kinase signaling in lymphocytes. Cell Metab. 2008, 8, 84-93. [CrossRef] [PubMed]

78. Sahni, J.; Tamura, R.; Sweet, I.R.; Scharenberg, A.M. TRPM7 regulates quiescent/proliferative metabolic transitions in lymphocytes. Cell Cycle 2010, 9, 3565-3574. [CrossRef] [PubMed]

79. Stritt, S.; Nurden, P.; Favier, R.; Favier, M.; Ferioli, S.; Gotru, S.K.; van Eeuwijk, J.M.; Schulze, H.; Nurden, A.T.; Lambert, M.P.; et al. Defects in TRPM7 channel function deregulate thrombopoiesis through altered cellular $\mathrm{Mg}^{2+}$ homeostasis and cytoskeletal architecture. Nat. Commun. 2016, 7, 11097. [CrossRef] [PubMed]

80. Krishnamoorthy, M.; Buhari, F.H.M.; Zhao, T.; Brauer, P.M.; Burrows, K.; Cao, E.Y.; Moxley-Paquette, V.; Mortha, A.; Zuniga-Pflucker, J.C.; Treanor, B. The ion channel TRPM7 is required for B cell lymphopoiesis. Sci. Signal. 2018, 11, eaan2693. [CrossRef] [PubMed]

81. Van Wijk, F.; Cheroutre, H. Mucosal T cells in gut homeostasis and inflammation. Expert Rev. Clin. Immunol. 2010, 6, 559-566. [CrossRef] [PubMed]

82. Kamada, N.; Nunez, G. Role of the gut microbiota in the development and function of lymphoid cells. J. Immunol. 2013, 190, 1389-1395. [CrossRef] [PubMed]

83. Campbell, D.J.; Butcher, E.C. Rapid acquisition of tissue-specific homing phenotypes by CD4 ${ }^{+} \mathrm{T}$ cells activated in cutaneous or mucosal lymphoid tissues. J. Exp. Med. 2002, 195, 135-141. [CrossRef] [PubMed]

84. Qiu, Y.; Wang, W.; Xiao, W.; Yang, H. Role of the intestinal cytokine microenvironment in shaping the intraepithelial lymphocyte repertoire. J. Leukoc. Biol. 2015, 97, 849-857. [CrossRef] [PubMed] 
85. Veldhoen, M.; Hocking, R.J.; Atkins, C.J.; Locksley, R.M.; Stockinger, B. TGFbeta in the context of an inflammatory cytokine milieu supports de novo differentiation of IL-17-producing T cells. Immunity 2006, 24, 179-189. [CrossRef] [PubMed]

86. Habtezion, A.; Nguyen, L.P.; Hadeiba, H.; Butcher, E.C. Leukocyte Trafficking to the Small Intestine and Colon. Gastroenterology 2016, 150, 340-354. [CrossRef] [PubMed]

87. Schon, M.P.; Arya, A.; Murphy, E.A.; Adams, C.M.; Strauch, U.G.; Agace, W.W.; Marsal, J.; Donohue, J.P.; Her, H.; Beier, D.R.; et al. Mucosal T lymphocyte numbers are selectively reduced in integrin alpha E (CD103)-deficient mice. J. Immunol. 1999, 162, 6641-6649. [PubMed]

88. Mokrani, M.; Klibi, J.; Bluteau, D.; Bismuth, G.; Mami-Chouaib, F. Smad and NFAT pathways cooperate to induce CD103 expression in human CD8 T lymphocytes. J. Immunol. 2014, 192, 2471-2479. [CrossRef] [PubMed]

89. Zierler, S.; Yao, G.; Zhang, Z.; Kuo, W.C.; Porzgen, P.; Penner, R.; Horgen, F.D.; Fleig, A. Waixenicin A inhibits cell proliferation through magnesium-dependent block of transient receptor potential melastatin 7 (TRPM7) channels. J. Biol. Chem. 2011, 286, 39328-39335. [CrossRef] [PubMed]

90. Kuras, Z.; Yun, Y.H.; Chimote, A.A.; Neumeier, L.; Conforti, L. KCa3.1 and TRPM7 channels at the uropod regulate migration of activated human T cells. PLoS ONE 2012, 7, e43859. [CrossRef] [PubMed]

91. Cai, Z.; Jitkaew, S.; Zhao, J.; Chiang, H.C.; Choksi, S.; Liu, J.; Ward, Y.; Wu, L.G.; Liu, Z.G. Plasma membrane translocation of trimerized MLKL protein is required for TNF-induced necroptosis. Nat. Cell Biol. 2014, 16, 55-65. [CrossRef] [PubMed]

92. Wolf, F.; Hilewitz, A. Hypomagnesaemia in patients hospitalised in internal medicine is associated with increased mortality. Int. J. Clin. Pract. 2014, 68, 111-116. [CrossRef] [PubMed]

93. Trapani, V.; Wolf, F.I.; Scaldaferri, F. Dietary magnesium: The magic mineral that protects from colon cancer? Magnes. Res. 2015, 28, 108-111. [CrossRef] [PubMed]

94. Chubanov, V.; Ferioli, S.; Wisnowsky, A.; Simmons, D.G.; Leitzinger, C.; Einer, C.; Jonas, W.; Shymkiv, Y.; Bartsch, H.; Braun, A.; et al. Epithelial magnesium transport by TRPM6 is essential for prenatal development and adult survival. eLife 2016, 5, e20914. [CrossRef] [PubMed]

95. Kau, A.L.; Ahern, P.P.; Griffin, N.W.; Goodman, A.L.; Gordon, J.I. Human nutrition, the gut microbiome and the immune system. Nature 2011, 474, 327-336. [CrossRef] [PubMed]

96. Malpuech-Brugere, C.; Nowacki, W.; Daveau, M.; Gueux, E.; Linard, C.; Rock, E.; Lebreton, J.; Mazur, A.; Rayssiguier, Y. Inflammatory response following acute magnesium deficiency in the rat. Biochim. Biophys. Acta 2000, 1501, 91-98. [CrossRef]

97. Ferrara, J.L.; Reddy, P. Pathophysiology of graft-versus-host disease. Semin. Hematol. 2006, 43, 3-10. [CrossRef] [PubMed]

98. Filipovich, A.H.; Weisdorf, D.; Pavletic, S.; Socie, G.; Wingard, J.R.; Lee, S.J.; Martin, P.; Chien, J.; Przepiorka, D.; Couriel, D.; et al. National Institutes of Health consensus development project on criteria for clinical trials in chronic graft-versus-host disease: I. Diagnosis and staging working group report. Biol. Blood Marrow Transplant. 2005, 11, 945-956. [CrossRef] [PubMed]

99. Ferrara, J.L.; Levine, J.E.; Reddy, P.; Holler, E. Graft-versus-host disease. Lancet 2009, 373, $1550-1561$. [CrossRef]

(C) 2018 by the authors. Licensee MDPI, Basel, Switzerland. This article is an open access article distributed under the terms and conditions of the Creative Commons Attribution (CC BY) license (http://creativecommons.org/licenses/by/4.0/). 